REVIEW

\title{
Identifying Predictors of Central Sleep Apnea/Cheyne-Stokes Breathing in Chronic Heart Failure: a Pathophysiological Approach
}

\author{
Aneliya I. Draganova, Kiril V. Terziyski, Stefan S. Kostianev \\ Department of Pathophysiology, Faculty of Medicine, Medical University of Plovdiv, Plovdiv, Bulgaria
}

\section{Correspondence:}

Aneliya I. Draganova, Department of Pathophysiology, Faculty of Medicine, Medical University of Plovdiv, 15a Vassil Aprilov Blvd., 4002 Plovdiv, Bulgaria

E-mail:

adraganova@pathophysiology.info Tel: +359 884213500

Received: 18 Feb 2016

Accepted: 11 July 2016

Published Online: 10 Oct 2016

Published: 23 Dec 2016

Key words: central sleep apnea, Cheyne-Stokes breathing, chronic heart failure, prediction, pathophysiology

Citation: Draganova Al, Terziyski KV, Kostianev SS. Identifying predictors of central sleep apnea/Cheyne-Stokes breathing in chronic heart failure: a pathophysiological approach.

Folia Medica 2016;58(4):225-233

doi: 10.1515/folmed-2016-0037
Chronic heart failure (CHF) is a major health problem associated with increased mortality, despite modern treatment options. Central sleep apnea (CSA)/CheyneStokes breathing (CSB) is a common and yet largely under-diagnosed co-morbidity, adding significantly to the poor prognosis in CHF because of a number of acute and chronic effects, including intermittent hypoxia, sympathetic overactivation, disturbed sleep architecture and impaired physical tolerance. It is characterized by repetitive periods of crescendo-decrescendo ventilatory pattern, alternating with central apneas and hypopneas. The pathogenesis of CSA/CSB is based on the concept of loop gain, comprising three major components: controller gain, plant gain and feedback gain. Laboratory polysomnography, being the golden standard for diagnosing sleep-disordered breathing (SDB) at present, is a costly and highly specialized procedure unable to meet the vast diagnostic demand. Unlike obstructive sleep apnea, CSA/CSB has a low clinical profile. Therefore, a reliable predictive system is needed for identifying CHF patients who are most likely to suffer from CSA/CSB, optimizing polysomnography use. The candidate predictors should be standardized, easily accessible and low-priced in order to be applied in daily medical routine.

The present review focuses on a pathophysiological approach to the selection of some predictors based on parameters reflecting the etiology, the pathogenesis and the consequences of CSA/CSB in CHF.

\section{INTRODUCTION}

Chronic heart failure (CHF) is a major health problem, associated with increased mortality in all age groups and especially among the elderly people (over 65 years) despite modern treatment. ${ }^{1}$ It is increasingly prevalent, affecting $1-2 \%$ of the population in the developed countries. ${ }^{2}$ Its clinical course and prognosis depend on the presence of various concomitant diseases and conditions, therefore, their proper identification and subsequent treatment are of primary importance. ${ }^{3}$

Among the most significant conditions accelerating the progression of $\mathrm{CHF}$ is the sleep-disordered breathing (SDB). It presents as repetitive episodes of a cessation (apnea) or a partial decrease (hypopnea) of the airflow, accompanied by desaturations and disturbed sleep architecture. Central sleep apnea (CSA) usually develops as a result of an instabil- ity in the breathing control system, manifesting with an absence of respiratory effort during the apneic phase. Cheyne-Stokes breathing (CSB) is a form of periodic breathing in which periods of crescendo-decrescendo ventilatory pattern alternate with central apneas and hypopneas, often referred to as $\mathrm{CSA} / \mathrm{CSB}$.

A review of the studies on SDB in CHF shows a high prevalence of sleep apnea among this population. Moreover, CSA/CSB was detected in $30-50 \%$ of the patients, while obstructive sleep apnea (OSA) - in $20-40 \% .{ }^{4}$ The great variability in the prevalence, the type and the severity of the SDB among the CHF population could be attributed to several factors. The focus of attention should be directed to the significant methodological differences, the lack of universal diagnostic criteria, the heterogeneity in the patients' characteristics, including different types of 
heart failure - with preserved or reduced ejection fraction, and the diversity in the therapy (Table 1).

The matter is further complicated by the possibility that a single patient may present with predominantly one type, both types of sleep apnea (OSA and CSA), or even a shift between them within a single night. ${ }^{6,16}$ Furthermore, elements of the CheyneStokes breathing pattern with waxing and waning ventilation can be observed even during obstructive events. Accordingly, Tkacova et al. hypothesize that both central and obstructive events are a part of a vicious cycle, including cardio-vascular, pulmonary and autonomic nervous mechanisms, adding to the progressive heart function decline. ${ }^{16}$

\section{PATHOGENESIS OF THE CHEYNE-STOKES RES- PIRATION ACCORDING TO THE LOOP GAIN THEORY}

According to the chemoreflex instability hypothesis CSA is explained as a self-sustaining oscillation resulting from an alteration in the closed breathing control system. ${ }^{17,18}$ It is based on the concept of "loop gain" - an engineering term, used to describe the stability of a system regulated by a negative feedback mechanism. The loop gain can be defined as the ratio between the magnitude of the response to a change in a certain controlled variable and the subsequent effect exerted on the amplitude of the latter. Thus, the loop gain reflects the propensity of the system for destabilization, and, in terms of the respiratory control - for development of periodic breathing. The relationship between the alterations occurring in CHF and the pathogenesis of CSB according to the loop gain theory is shown in Fig. 1.

The loop gain consists of three components: controller gain, plant gain and feedback gain. In fact, the controller gain represents the classical understanding of the control of breathing through central and peripheral chemoreceptors and reflects the ventilatory response to $\mathrm{CO}_{2}$ changes. The plant gain accounts for the efficiency of ventilation in eliminating $\mathrm{CO}_{2}$. A prerequisite for the destabilization of a negative feedback system is the time delay in the response of the control mechanisms, represented by the feedback gain. Enhancement in any of these three components would result in ventilatory instability expressed as CSA/CSB (Fig. 1).

\section{ENHANCED CONTROLLER GAIN}

The main pathological factor leading to and maintaining the CSB is the instability in $\mathrm{CO}_{2}$ concentration, fluctuating around the apneic threshold. ${ }^{19,20}$ In CHF patients, however, there are several other factors, contributing to the development of periodic breathing, such as decreased partial pressure of carbon dioxide $\left(\mathrm{pCO}_{2}\right)$ levels, both during sleep and wakefulness, as well as the absence of adequate decrease in the apneic threshold. ${ }^{18,21}$ Lorenzi-Filho

Table 1. Some of the most important studies reporting the prevalence of sleep-disordered breathing in chronic heart failure

\begin{tabular}{|c|c|c|c|c|c|c|c|}
\hline Study & $\mathbf{n}$ & $\begin{array}{c}\text { Age } \\
\text { (years) }\end{array}$ & Method & $\begin{array}{c}\text { AHI } \\
\left(\text { count.h }^{-1}\right)\end{array}$ & SDB\% & CSA\% & OSA $\%$ \\
\hline Arzt, $2016^{3}$ & 6876 & $69 \pm 11$ & $\mathrm{PG}$ & $\geq 15$ & 46 & NA & NA \\
\hline Macdonald, $2008^{5}$ & 108 & $57 \pm 11$ & PG & $>15$ & 61 & 31 & 30 \\
\hline Javaheri, 1998*6 & 81 & $66 \pm 9$ & PSG & $\geq 15$ & 51 & 40 & 11 \\
\hline Ferrier, $2005^{7}$ & 53 & $60 \pm 10$ & PSG & $\geq 10$ & 68 & 15 & 53 \\
\hline Christ, $2007^{8}$ & 102 & $60 \pm 14$ & $\mathrm{PG}$ & $\geq 10$ & 55 & 37 & 17 \\
\hline Oldenburg, $2007^{9}$ & 700 & $65 \pm 10$ & PG & $\geq 5$ & 76 & 40 & 36 \\
\hline Schulz, $2007^{10}$ & 203 & $65 \pm 1$ & PG & $\geq 10$ & 71 & 28 & 43 \\
\hline Yumino, $2009^{11}$ & 218 & $56 \pm 13$ & PSG & $\geq 15$ & 47 & 21 & 26 \\
\hline Vazir, $2007^{12}$ & 55 & $61 \pm 12$ & PSG & $>15$ & 53 & 38 & 15 \\
\hline Bitter, $2012^{13}$ & 1500 & $68 * *$ & PSG/PG & $>5$ & 71.1 & 48.9 & 22.2 \\
\hline Gellen $2016^{14}$ & 376 & $59 \pm 13$ & PG & $\geq 15$ & 55 & NA & NA \\
\hline
\end{tabular}

Legend: PG - polygraphy; PSG - polysomnography; AHI - apnea-hypopnea index, SDB - sleep-disordered breathing, CSA - central sleep apnea, OSA - obstructive sleep apnea (data give the percentages of patients with SDB/CSA/OSA out of the total number of patients in the respective study), *data for the SDB group; **data for the CSA group. 


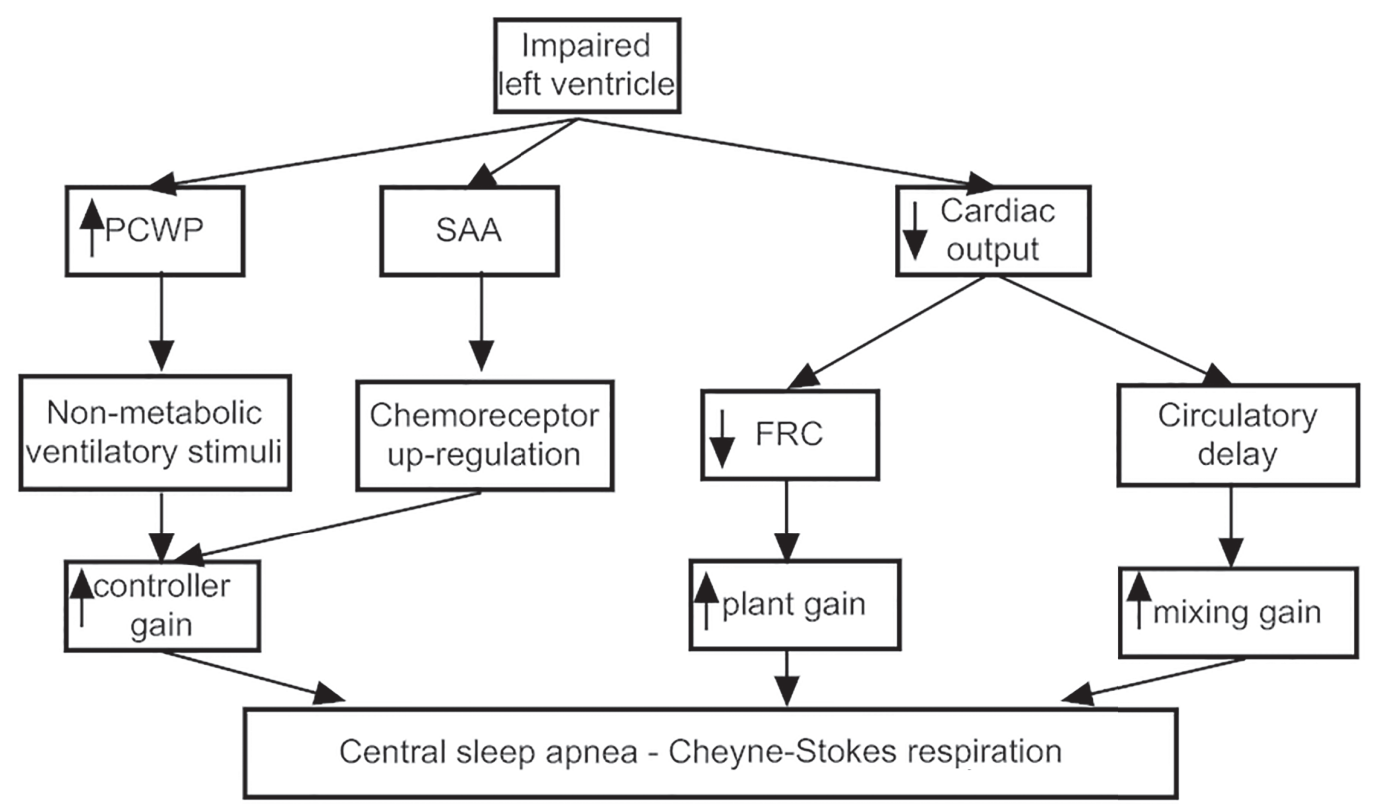

Legend: PCWP - pulmonary capillary wedge pressure, SAA - sympathetic-adrenal activation, FRC - functional residual capacity.

Figure 1. The relationship between the alterations occurring in CHF and the pathogenesis of CSB according to the loop gain theory (based on Naughton ${ }^{5}$ ).

et al. managed to eliminate successfully the CSB (AHI $38.7 \pm 17.0$ vs $2.3 \pm 2.9$ ) and the associated desaturations in $10 \mathrm{CHF}$ patients by exposing them to small concentrations of $\mathrm{CO}_{2}$ through inhalation, which was accompanied by a slight increase in the transcutaneous $\mathrm{pCO}_{2}$. This experiment further implies the significance of even minimal fluctuations of $\mathrm{pCO}_{2}$ for the development and maintenance of periodic breathing in CHF patients. ${ }^{22}$

\section{ENHANCED PLANT GAIN}

Based on the hypothesis that increased left ventricular volume in $\mathrm{CHF}$ is associated with pulmonary congestion and a predisposition to CSB, Tkacova et al. ${ }^{23}$ investigated patients with non-ischemic cardiomyopathy and demonstrated that the end systolic and the end diastolic volumes of the left ventricle are twice as big in the CSB group compared to those without CSB. Solin et al. ${ }^{24}$ reported similar results, demonstrating approximately the two-fold increase in the pulmonary capillary wedge pressure (PCWP) in patients with CHF and CSA, accompanied by hypocapnia, as compared to those with OSA or without SDB. Furthermore, PCWP was found to correlate negatively with the level of $\mathrm{pCO}_{2}$ and positively with the severity and frequency of the central apneas. ${ }^{24}$ Therefore, increased PCWP could be an alarming signal for the presence of CSA, especially taking into account the increased mortality among CHF patients with increased vascular pressures.

\section{ENHANCED FEEDBACK GAIN}

The prolonged circulation time causes a delay in the transmission of the changes in the arterial blood gases to the chemoreceptors. Theoretically, this can lead to a destabilization of the respiratory control. The increased arterial circulatory time, caused by heart failure, changes the loop gain activity in a way that it enhances the possibility for the development of respiratory oscillations, thus stimulating controller gain to execute a "right answer at the wrong time". However, the data concerning the significance of time delay in the pathogenesis of CSA are contradictory. Several studies suggest its importance in the development of CSA. ${ }^{17,18,25,26}$ In a study of 10 patients with idiopathic CSA and normal cardiac function and $10 \mathrm{CSA} / \mathrm{CSB}$ patients with CHF, Hall et al. demonstrated that SDB is due to the dips of $\mathrm{CO}_{2}$ levels below the AT, but are not associated with the degree of circulatory delay. The authors concluded that rather than initiating periodic breathing, the circulatory delay determines hyperpnea length and cycle duration once it has already been established. ${ }^{17}$

\section{THE NEED FOR PREDICTIVE FACTORS}

Irrespective of the exact intricate pathogenetic mechanisms of CSB, its presence in CHF patients 
worsens the overall prognosis ${ }^{27,28}$ and needs targeted treatment $\mathrm{t}^{29,30}$. Therefore, a reliable screening system for its timely detection is required. At present, the golden standard for diagnosing CSA/CSB is laboratory polysomnography, which can differentiate the various types of $\mathrm{SDB}^{7}$ and determine the need of treatment. However, polysomnography is an expensive, laborious and highly specialized procedure. Besides, the available laboratories are not able to meet the diagnostic demand of all the patients with CHF. ${ }^{12,26}$ Type 4 screening devices (one or two channels) are a meaningful solution to detect patients with SDB. However, they are not available to most of the general practitioners and even cardiologists who take care of patients with CHF. A practical approach to overcome these problems is the establishment of a predictive system, aiming at selecting the appropriate patients for optimal use of polysomnography, rather than avoiding it. The "obvious" "candidate predictors" are those derived from the clinical history, the physical examination, as well as some distinctive characteristics of the disease or laboratory parameters. The chosen ones should be clearly defined, informative, standardized, easily accessible and low-priced, in order to be applied in the medical routine.

A pathophysiological approach for the selection of the predictors is their classification into 3 main groups: 1) The presence/absence of risk factors for the development of CSA in CHF patients (etiological); 2) Parameters, reflecting the pathogenesis of CSA in CHF patients (pathogenetic) and 3) Parameters, reflecting the consequences of the existing CSA in CHF patients (symptomatic).

Such an approach, applied to the available literature data and the potential predictors, in our view, is presented in Fig. 2.

\section{ETIOLOGICAL PARAMETERS}

Anthropometric MEASUREMENTS - AGe, Gender, BODY MASS INDEX (BMI), NECK CIRCUMFERENCE

Older age and male gender have been clearly identified as significant independent risk factors for the presence of CSA in CHF patients ${ }^{13,27}$, irrespective of BMI, left ventricular ejection fraction (LVEF) and New York Heart Association (NYHA) class. ${ }^{11}$

The factors behind the gender differences are not entirely elucidated. Central phenomena usually appear in light sleep or in the transition wakefulnesssleep, especially after an arousal or sleep-phase change. Consequently, the fact that men have more fragmented sleep, with less stable sleep structure, less slow wave sleep and an increased number of sleep-wake transitions ${ }^{31,32}$, could be a possible explanation. On the other hand, central events are usually triggered by a phenomenon that causes hyperventilational hypocapnia, such as an obstructive apnea. ${ }^{4,11,16}$ Therefore, the higher prevalence of OSA in males can partially explain the higher prevalence and severity of CSA in male patients with CHF. ${ }^{32}$

Obesity is a classical risk factor for OSA. ${ }^{13}$ It could be speculated that it is among the risk factors for CSA as well, taking into account the influence of adipokines on respiratory control ${ }^{33}$ and the fact

\section{PREDICTORS}

\begin{tabular}{|c|c|c|c|c|c|}
\hline & Etiologic & \multicolumn{3}{|c|}{ Pathogenetic } & Symptomatic \\
\hline \multirow{4}{*}{$\begin{array}{l}\checkmark \\
\checkmark \\
\checkmark \\
\checkmark \\
\checkmark\end{array}$} & \multirow{4}{*}{$\begin{array}{l}\text { Anthropometry } \\
\text { Medical history } \\
\text { EchoCG } \\
\text { NYHA class } \\
\text { Laboratory } \\
\text { parameters }\end{array}$} & Controller gain & Plant gain & Mixing gain & Symptoms \\
\hline & & $\begin{array}{ll}\checkmark \quad \text { Respiratory } \\
\text { control }\end{array}$ & $\begin{array}{l}\text { PFT } \\
\text { EchocG }\end{array}$ & $\checkmark$ EchoCG & $\begin{array}{ll}\checkmark & \text { ESS } \\
\checkmark & \text { MLHFQ }\end{array}$ \\
\hline & & \multicolumn{3}{|c|}{ Loop gain in general } & Complications \\
\hline & & \multicolumn{3}{|c|}{$\begin{array}{ll}\checkmark & \text { Cardiopulmonary exercise testing (CPET) } \\
\checkmark & \text { Hypoxic provocation } \\
\checkmark & \text { BGA }\end{array}$} & $\begin{array}{ll}\checkmark & \text { ECG/HRV } \\
\checkmark & \text { CPET }\end{array}$ \\
\hline
\end{tabular}

Legend: EchoCG - Echocardiography, NYHA - New York Heart Association, BGA - blood gas analysis, PFT - pulmonary function test, ESS - Epwort Sleepiness Scale, MLHFQ - Minnesota Living With Heart Failure Questionnaire, ECG - electrocardiography, HRV - heart rate variability, CPET - cardiopulmonary exercise testing

Figure 2. A pathophysiological approach to identify predictors for the presence of central sleep apnea in patients with chronic heart failure. 
that obstructive events can also trigger CSA in case of a predisposition. ${ }^{4,11,16}$

The neck circumference is a simple anthropometric parameter that has been used in the prediction of OSA. As it was summarized by Bradley et al. ${ }^{34}$, it is influenced by the rostral fluid shift during the night, present in patients with CHF. The rostral fluid shift, however, affects also the lungs (increasing pulmonary congestion), which is a part of the CSA pathophysiology. Thus, increased neck circumference, although not causatively related to the occurrence of CSA, may still correlate with it.

Laboratory parameters - Brain Natriuretic Peptide (BNP), C-REACTIVE PROTEIN (CRP)

BNP levels proportionately increase with $\mathrm{CHF}$ progression and are routinely used to assess the severity of the syndrome. ${ }^{35}$ The mechanisms by which CSA/CSB influences the levels of BNP are not well-understood. The sympathetic overactivation, observed in CSA, could cause repetitive surges of blood pressure and heart rate, thus increasing the left ventricular afterload. Furthermore, the hypoxemia can also stimulate BNP secretion. ${ }^{36}$ Carmona-Bernal et al. report a three-fold increase in BNP levels in CHF patients with CSA, as compared to those without CSA and similar NYHA class and LVEF. ${ }^{28}$ Bitter et al. also report higher levels of NT-BNP in the CSA group compared not only to patients without SDB, but also to OSA patients. ${ }^{13}$

Several studies report increased levels of CRP in CHF patients. ${ }^{37,38}$ According to the cytokine hypothesis, the activation of the immune system plays a certain role in the pathogenesis of $\mathrm{CHF}$, underlining the importance of some pro-inflammatory cytokines in the development of the ventricular dysfunction. ${ }^{38}$ Anand et al. demonstrated that elevated CRP levels correlate with greater CHF severity, regardless of its cause (ischemic or non-ischemic), and also with the subsequent adverse events and mortality. ${ }^{39}$ The mechanisms linking increased levels of CRP and CHF remain not entirely understood. A possible explanation is that IL-6, secreted by the cardiac myocytes when exposed to hypoxic stress, is a direct stimulus for CRP production by the hepatocytes. ${ }^{38,40}$

Parameters Reflecting the SEVERity of CHF ECHOCARDIOGRAPHY (ECHOCG), NYHA CLASS

The standard measurements used for assessment of the severity of CHF (NYHA class and ejection fraction) do not considerably differ between CHF patients with and without accompanying SDB. $8,41,42$ Despite the correlation between the severity of CHF and the prevalence of CSA, the latter is present in patients with milder forms of CHF, which makes NYHA class an unreliable criterion for determining the CSA risk. ${ }^{42}$

CSA/CSB has also been found in CHF patients with preserved EF (HFPEF). In a study of 244 consecutive patients with HFPEF, Bitter et al. found that sleep apnea (apnea-hypopnea index (AHI) $\geq 15 /$ hour) was present in $48 \%$ of the patients $(25 \%$ OSA and $23 \% \mathrm{CSA}){ }^{43}$ Therefore, EF is inapplicable as a predictive tool for the presence of CSA/CSB.

\section{PATHOGENETIC PREDICTORS (ASSOCIATED WITH ELEMENTS OF THE CSA PATHOGENESIS IN CHF)}

\section{INDICATORS OF ENHANCED CONTROLLER GAIN}

The measurement of arterial blood gases provides indirect information about the controller gain (in association with the plant gain). According to Szollosi et al., arterial hypoxia is an important prognostic factor for the presence of CSA in CHF. ${ }^{44}$ The authors report that patients with CSA had significantly lower values of $\mathrm{pCO}_{2}$ and diffusing capacity, compared to the OSA and the stable-breathing groups. ${ }^{44}$ Since decreased diffusing capacity is a mechanism for the occurrence of hypoxia and hypocapnia, the role of the partial pressure of oxygen $\left(\mathrm{pO}_{2}\right)$ as an independent risk factor could be questioned. However, lower $\mathrm{pO}_{2}$ values in CSA patients have not been found to be an independent risk factor, in the study of Bitter et al. ${ }^{13}$ On the contrary, the hypocapnia $\left(\mathrm{pCO}_{2}\right.$ $<35$ ) is a major criterion in the suggested screening algorithm in CHF patients and in the subsequent recommendation for polysomnography. It should be stated that the arterial blood gases $\left(\mathrm{pO}_{2}\right.$ and $\left.\mathrm{pCO}_{2}\right)$ are indicative not only for the controller gain and the plant gain, but being the main controlled parameters, represent the loop gain system as a whole.

INDICATORS OF ENHANCED PLANT GAIN

Increased plant gain reflects the excessive efficiency of the ventilation in regard to the exhaled $\mathrm{CO}_{2}$. The plant gain is dependent on pulmonary gas reserves, tissue oxygen and $\mathrm{CO}_{2}$ reserves and metabolism intensity. ${ }^{44}$

Breathing at a decreased functional residual capacity (FRC) makes $\mathrm{CO}_{2}$ elimination more effective. Reduced pulmonary volumes promote breathing instability, which can explain the increased propensity to CSA/CSB in supine position. ${ }^{4}$ The decreased FRC in CHF patients leads to a premature closure of the airways during tidal breathing ${ }^{45}$, which results 
in an irregular distribution of the ventilation and a disturbed gas transfer in the lungs. The impaired gas exchange is partially compensated by an increase in the pulmonary ventilation at the expense of hyperpnea and tachypnea. ${ }^{45}$ In other words, the decreased FRC is a prerequisite for a relative hyperventilation and the development of CSA/CSB.

According to the study by Szollosi et al., the decreased diffusion capacity is an important and independent predictor for the presence of CSA in CHF patients showing a moderate correlation with the AHI. ${ }^{44}$ In this study, however, the patients within the CSA group had considerably lower levels of $\mathrm{pCO}_{2}$, a fact that questions the independent predictive value of the decreased diffusion capacity.

INDICATORS OF ENHANCED FEEDBACK GAIN

An indirect assessment of the circulatory delay could be acquired from parameters reflecting the impaired hemodynamics in CHF, such as LVEF and BNP, which have been discussed earlier.

The direct evaluation of the circulatory delay is expressed as LECT (lung-to-ear circulation time), which is defined as the time from the end of the apneic pause to the nadir of saturation measured at the ear lobe. ${ }^{46}$ However, the methodology of LECT measurement is too complex to be applicable as a screening tool.

Parameters of enhanced loop gain (as a Whole)

Presence of periodic breathing while awake (during rest or cardio-pulmonary exercise testing (CPET))

CSB in CHF has also been observed during wakefulness ${ }^{26,47}$ and has been associated with increased mortality and shorter transplant-free survival. It is determined by low cardiac index and prolonged circulation time ${ }^{26}$ and has been related to sympathetic overactivation and increased BNP levels. ${ }^{47}$ The association of daytime CSB with more severe clinical course, lower LVEF, decreased functional capacity and hypocapnia at rest, suggests common pathogenetic mechanisms for the development of daytime and nighttime CSB in CHF patients.

Periodic breathing has been registered also during CPET. In the study by Roche et al., the presence of periodic breathing at rest and during the first 4 minutes of veloergometry showed strikingly high sensitivity (92.9\%), specificity $(94.1 \%)$ and predictive strength (93.3\%) for the presence of CSA in CHF. ${ }^{48}$

\section{SYMPTOMATIC PARAMETERS (ASSOCIATED WITH THE CONSEQUENCES OF CSA+CHF)}

Atrial FIBRILlation (AF)

A relation between atrial fibrillation and the presence of SDB has been demonstrated. ${ }^{15}$ This association is probably bi-directional, since AF could be described as a complication of CSA and, at the same time, as a part of its pathogenesis. It is possible that $\mathrm{AF}$ is a consequence of CHF, because of the sympathetic overactivation, which influences the cardiac conduction system. On the other hand, CHF and AF may share common etiology, e.g. coronary artery disease, which may also affect the cardiac conduction system.

\section{HEART RATE VARIABILITY (HRV)}

The dysregulation of the autonomic nervous system, assessed by HRV analysis, is one of the most pronounced alterations, occurring in $\mathrm{CHF}^{49}$ Vazir et al. reported that the HRV is considerably increased in CHF patients with SDB, as compared to those without SDB. ${ }^{41}$ Tateishi et al. also found increased prevalence of very low frequency (VLF) oscillations in CHF patients with CSB and demonstrated that changes in the HRV (expressed as a ratio CSB/VLF oscillations- $80 \%$ ), are a marker of poor prognosis. ${ }^{50}$ A serious disadvantage of the method is its inapplicability in the presence of AF or other conductive disorders. Another factor influencing HRV parameters is the drug therapy and especially beta-blockers, commonly prescribed to CHF patients.

EXCESSIVE DAYTIME SLEEPINESS (EDS) AND QuALITY OF LIFE (QOL)

Unlike OSA, the clinical profile of CSA is poor. Usually, patients do not report the typical loud snoring and/or EDS. ${ }^{7,41,42}$ In most cases, the precise evaluation of EDS is problematic, since the available methods rely mainly on subjective assessment, therefore, ESS alone could not identify patients with SDB. In addition, the symptoms of CHF can also cause sleep fragmentation and bad sleep quality and provoke some daytime complaints, even in the absence of CSA. ${ }^{7}$ The prevalence of ESS varies with age, showing an increased predominance and morbidity among the elderly, who actually constitute the main CHF contingent. ${ }^{51}$

CHF patients have considerably impaired quality of life as compared to patients with other chronic conditions. ${ }^{52}$ Hoekstra et al. demonstrated that QoL is a predictor of 3-year mortality in CHF patients. ${ }^{53}$ However, according to Ferrier et al., the QoL in 
CHF patients, measured by Minnesota Questionnaire (MLHFQ), does not show any differences between the groups with and without CSA. ${ }^{7}$

Physical CAPACITY (CARDIO-PULMONARY EXERCISE TEST)

OSA has been associated with decreased physical capacity, because of sleep alterations, including: 1) Hypoxia (leading to endothelial dysfunction, sympathetic activation and neuronal loss), 2) Arousals (associated with peripheral and muscle vasoconstriction), 3) Sleep fragmentation (ESS), 4) Increased breathing effort (left ventricle damage). The first three factors are present in CSA as well and, therefore, decreased physical activity is expected in CSA. However, there are only a few small studies on the topic reporting contradictory results. ${ }^{41,42}$

\section{CONCLUSION}

There is a striking contrast between the substantial medical, social and economic impact of the CSA/CSB in $\mathrm{CHF}$ and the lack of well-established guidelines and algorithms for its diagnosis and treatment. Most of the recent efforts have been directed towards improvement of the treatment modalities, while strict criteria to go by in treatment are absent. Another important problem is the incapability of the available sleep laboratories to meet the overwhelming demand for polysomnography of CHF patients. Taking into account the reported prevalence of CSA in CHF, a reliable screening system, based on certain predictive factors, would greatly unload the healthcare system. Thus, the lack of an easily available and cheap screening method is a significant problem that has been only modestly addressed in the last years. We propose an approach, reflecting the pathophysiology of the respiratory control instability in CHF, based on the loop gain concept, in the process of looking for new predictors (Table 2). The proposed structure for a screening system may be used as a theoretical background for prospective studies on the topic.

\section{REFERENCES}

1. Barsheshet A, Shotan A, Cohen E, et al. Predictors of long-term (4-year) mortality in elderly and young patients with acute heart failure. Eur J Heart Fail 2010;12(8):833-40.

2. Bundkirchen A, Schwinger RH. Epidemiology and economic burden of chronic heart failure. Euro Heart J Suppl 2004;6(suppl D):57-60.

3. Arzt M, Woehrle H, Oldenburg O, et al. Prevalence and predictors of sleep-disordered breathing in patients with stable chronic heart failure: The SchlaHF Registry. JACC Heart Fail 2016;4(2):116-25.
4. Naughton MT, Lorenzi-Filho G. Sleep in heart failure. Prog Cardiovasc Dis 2009;51(4):339-49.

5. Macdonald M, Fang J, Pittman SD, et al. The current prevalence of sleep disordered breathing in congestive heart failure patients treated with beta-blockers. J Clin Sleep Med 2008;4(1):38-42.

6. Javaheri S, Parker TJ, Liming JD, et al. Sleep apnea in 81 ambulatory male patients with stable heart failure. Types and their prevalences, consequences, and presentations. Circulation 1998;97:2154-9.

7. Ferrier K, Campbell A, Yee B, et al. Sleep-disordered breathing occurs frequently in stable outpatients with congestive heart failure. Chest 2005;128(4):2116-22.

8. Christ M, Sharkova Y, Fenske H, et al. Brain natriuretic peptide for prediction of Cheyne-Stokes respiration in heart failure patients. Int $\mathrm{J}$ Cardiol 2007;116(1):62-9.

9. Oldenburg O, Lamp B, Faber L, et al. Sleep-disordered breathing in patients with symptomatic heart failure: a contemporary study of prevalence in and characteristics of 700 patients. Eur J Heart Fail 2007;9(3):251-7.

10.Schulz R, Blau A, Börgel J, et al. Sleep apnoea in heart failure. Eur Respir J 2007;29(6):1201-5.

11. Yumino D, Wang H, Floras JS, et al. Prevalence and physiological predictors of sleep apnea in patients with heart failure and systolic dysfunction. J Card Fail 2009;15(4):279-85.

12. Vazir A, Hastings PC, Dayer M, et al. A high prevalence of sleep disordered breathing in men with mild symptomatic chronic heart failure due to left ventricular systolic dysfunction. Eur J Heart Fail 2007;9(3):243-50.

13. Bitter T, Westerheide N, Hossain SM, et al. Symptoms of sleep apnoea in chronic heart failure - results from a prospective cohort study in 1,500 patients. Sleep Breath 2012;16(3):781-91.

14. Gellen B, Canouï-Poitrine F, Boyer L, et al. Apneahypopnea and desaturations in heart failure with reduced ejection fraction: Are we aiming at the right target? Int J Cardiol 2016;203:1022-8.

15. Sin DD, Fitzgerald F, Parker JD, et al. Risk factors for central and obstructive sleep apnea in 450 men and women with congestive heart failure. Am J Respir Crit Care Med 1999;160(4):1101-6.

16. Tkacova R, Wang H, Bradley TD. Night-to-night alterations in sleep apnea type in patients with heart failure. J Sleep Res 2006;15(3):321-8.

17. Hall MJ, Xie A, Rutherford R, et al. Cycle length of periodic breathing in patients with and without heart failure. Am J Respir Crit Care Med 1996;154(2):376-81.

18. Naughton M, Benard D, Tam A, et al. Role of hyperventilation in the pathogenesis of central sleep apneas in patients with congestive heart failure. Am 
Rev Respir Dis 1993;148:330-8.

19. Bradley TD, Floras JS. Pathophysiologic and therapeutic implications of sleep apnea in congestive heart failure. J Card Fail 1996;2(3):223-40.

20.Bradley TD, Lorenzi-Filho G. Pathophysiological interactions between sleep apnea and the heart. Lung Biology in Health and Disease 2001;157:577-612.

21.Xie A, Skatrud JB, Puleo DS, et al. Apnea-hypopnea threshold for $\mathrm{CO}_{2}$ in patients with congestive heart failure. Am J Respir Crit Care Med 2002;165(9):1245-50.

22. Lorenzi-Filho G, Rankin F, Bies I. Effects of inhaled carbon dioxide and oxygen on Cheyne-Stokes respiration in patients with heart failure. Am J Respir Crit Care Med 1999;159(5):1490-8.

23. Tkacova R, Hall MJ, Liu PP, et al. Left ventricular volume in patients with heart failure and CheyneStokes respiration during sleep. Am J Respir Crit Care Med 1997;156(5):1549-55.

24. Solin P, Bergin P, Richardson M, et al. Influence of pulmonary capillary wedge pressure on central apnea in heart failure. Circulation 1999;99(12):1574-9.

25. Guyton AC, Crowell JW, Moore JW. Basic oscillating mechanism of Cheyne-Stokes breathing. Am J Physiol 1956;187(2):395-8.

26. Mortara A, Sleight P, Pinna GD, et al. Association between hemodynamic impairment and CheyneStokes respiration and periodic breathing in chronic stable congestive heart failure secondary to ischemic or idiopathic dilated cardiomyopathy. Am J Cardiol 1999;84(8):900-4.

27. Ancoli-Israel S, DuHamel ER, Stepnowsky C, et al. The relationship between congestive heart failure, sleep apnea, and mortality in older men. Chest 2003;124(4):1400-5.

28.Carmona-Bernal C, Quintana-Gallego E, Villa-Gil $\mathrm{M}$, et al. Brain natriuretic peptide in patients with congestive heart failure and central sleep apnea. Chest 2005;127(5):1667-73.

29. Arzt M, Floras JS, Logan AG, et al. Suppression of central sleep apnea by continuous positive airway pressure and transplant-free survival in heart failure: a post hoc analysis of the Canadian Continuous Positive Airway Pressure for Patients with Central Sleep Apnea and Heart Failure Trial (CANPAP). Circulation 2007;115(25);3173-80.

30. Arzt M, Schulz M, Schroll S, et al. Time course of continuous positive airway pressure effects on central sleep apnoea in patients with chronic heart failure. J Sleep Res 2009;18(1):20-5.

31. Hume K, Van F, Watson A. A field study of age and gender differences in habitual adult sleep. J Sleep Res 1998;7(2):85-94.

32. Silva RS, Figueiredo AC, Mady C, et al. Breathing disorders in congestive heart failure: gender, etiology and mortality. Braz J Med Biol Res 2008;41(3):215-22.

33. Cundrle I, Somers VK, Singh P, et al. Leptin deficiency promotes central sleep apnea in patients with heart failure. Chest 2014;145(1):72-8.

34. White LH, Bradley TD. Role of nocturnal rostral fluid shift in the pathogenesis of obstructive and central sleep apnoea. J Physiol 2013;591(5):1179-93.

35. Mukoyama M, Nakao K, Saito $Y$, et al. Increased human brain natriuretic peptide in congestive heart failure. N Engl J Med 1990;323(11);757-8.

36. Ando T, Yamaki KI, Takagi K, et al. Plasma concentrations of atrial, brain, and C-type natriuretic peptides and endothelin-1 in patients with chronic respiratory diseases. Chest 1996;110(2):462-8.

37. Pye M, Rae AP, Cobbe SM. Study of serum Creactive protein concentration in cardiac failure. $\mathrm{Br}$ Heart J 1990;63(4):228-30.

38. Sato Y, Takatsu Y, Kataoka K, et al. Serial circulating concentrations of $\mathrm{C}$-reactive protein, interleukin (IL)-4, and IL-6 in patients with acute left heart decompensation. Clin Cardiol 1999;22(12):811-3.

39. Anand IS, Latini R, Florea VG, et al. C-reactive protein in heart failure: prognostic value and the effect of valsartan. Circulation 2005;112(10):1428-34.

40. Yamauchi-Takihara K, Ihara Y, Ogata A, et al. Hypoxic stress induces cardiac myocyte-derived interleukin-6. Circulation 1995;91(5):1520-4.

41. Vazir A, Dayer M, Hastings PC, et al. Can heart rate variation rule out sleep disordered breathing in heart failure? Eur Respir J 2006;27(3): 571-7.

42. Arzt M, Harth M, Luchner A, et al. Enhanced ventilatory response to exercise in patients with chronic heart failure and central sleep apnea. Circulation 2003;107(15):1998-2003.

43. Bitter T, Faber L, Hering D, et al. Sleep-disordered breathing in heart failure with normal left ventricular ejection fraction. Eur J Heart Fail 2009;11(6):602-8.

44. Szollosi I, Thompson BR, Krum H, et al. Impaired pulmonary diffusing capacity and hypoxia in heart failure correlates with central sleep apnea severity. Chest 2008;134(1):67-72.

45. Torchio R, Gulotta C, Greco-Lucchina P, et al. Closing capacity and gas exchange in chronic heart failure. Chest 2006;129(5):1330-36.

46. Lorenzi-Filho G, Genta PR, Figueiredo AC, et al. Cheyne-Stokes respiration in patients with congestive heart failure: causes and consequences. Clinics 2005;60(4):333-44.

47. Poletti R, Passino C, Giannoni A, et al. Risk factors and prognostic value of daytime Cheyne-Stokes respiration in chronic heart failure patients. Int $\mathrm{J}$ Cardiol 2009;137(1):47-53.

48. Roche F, Maudoux D, Jamon Y, et al. Monitoring of ventilation during the early part of cardiopulmonary 
exercise testing: The first step to detect central sleep apnoea in chronic heart failure. Sleep medicine 2008;9(4):411-7.

49. Ferguson DW, Berg WJ, Roach PJ, et al. Effects of heart failure on baroreflex control of sympathetic neural activity. Am J Cardiol 1992;69(5):523-31.

50. Tateisho O, Shouda T, Honda Y, et al. Apnearelated heart rate variability and its clinical utility in congestive heart failure outpatients. A.N.E 2002;7(2):127-32.

51.Bixler EO, Vgontzas AN, Lin HM, et al. Excessive daytime sleepiness in a general population sample: the role of sleep apnea, age, obesity, diabetes, and depression. J Clin Endocrinol Metab 2005;90(8):4510-5.

52.Lesman-Leegte I, Jaarsma T, Coyne JC, et al. Quality of life and depressive symptoms in the elderly: a comparison between patients with heart failure and age- and gender-matched community controls. J Card Fail 2009;15(1):17-23.

53. Hoekstra T, Jaarsma T, Veldhuisen DJ, et al. Quality of life and survival in patients with heart failure. Eur J Heart Fail 2013;15(1):94-102.

\title{
Идентификация предикторов центрального сонного апноэ (дыхание Чейна-Стокса) при хронической сердечной недостаточности: пато- физиологический подход
}

\author{
Анелия И. Драганова, Кирилл В. Терзийски, Стефан С. Костянев \\ Кафедра патофизиологии, Факультет медицины, Медицинский университет, Пловдив, Болгария
}

\begin{abstract}
Адрес для корреспонденции: Анелия И. Драганова, Кафедра патофизиологии, Факультет медицины, Медицинский университет - Пловдив, бул. Васила Априлова № $15 \mathrm{~A}$, Пловдив, 4002, Болгария E-mail: adraganova@pathophysiology.info

Тел.: +359884213500
\end{abstract}

Дата получения: 18 февраля 2016 г.

Дата приемки: 11 июля 2016 г. Дата онлайн публикации: 10 октября 2016 г.

Дата публикации: 23 декабря 2016 r.

Ключевые слова: центральное сонное апноэ, дыхание ЧейнаСтокса, хроническая сердечная недостаточность, предикторы, патофизиология

\section{Образец цитирования:} Draganova Al, Terziyski KV, Kostianev SS. Identifying predictors of central sleep apnea/CheyneStokes breathing in chronic heart failure: a pathophysiological approach.

Folia Medica 2016;58(4):225-233 doi: 10.1515/folmed-2016-0037
Хроническая сердечная недостаточность (ХCH) представляет серьезную проблему для здоровья, связанную с повышенной смертностью, несмотря на современные возможности лечения. Центральное сонное апноэ (ЦСА) / дыхание Чейна-Стокса (ДЧС) является часто встречающимся и, несмотря на это, в значительной степени редко диагностицируемым сопровождающим заболеванием, которое играет существенную роль в неблагоприятном прогнозе в случаях ХCH ввиду наличия ряда острых и хронических эффектов, включая периодическую гипоксию, симпатическую сверхактивность, нарушения архитектоники сна и нарушения физического толеранса. Характеризуется повторяющимся проявлением ромбовидного систолического шума выброса (кресчендо-декресчендо), вслед за которым наступает центральное апноэ и гипонея. Патогенез ЦСА/ДЧС основан на концепции цикла усиления, состоящего из трех основных компонентов: респираторный контроллер, эффективность выделения CO2 и задержка, проистекающая в результате соединения гемоглобина и кровообращения. Лабораторная полисомнография является золотым стандартом при диагностике нарушений дыхания во время сна (НДС), но на данный момент является дорогостоящей и высокоспециализированной процедурой, не способной удовлетворить большой спрос в области диагностики. По сравнению с обструктивным сонным апноэ ЦСА/ДЧС отличается низким клиническим профилем. Поэтому необходима надежная предиктивная система для идентификации пациентов с ХCH, по всякой вероятности страдающих ЦСА/ДЧС, за счет оптимизации использования полисомнографии. Возможные предикторы должны быть стандартизованными, легко доступными и недорогостоящими, в целях их применения в повседневной медицинской практике.

Данный обзор фокусируется на патофизиологическом подходе к выбору предикторов, в основе которого стоят параметры, отражающие этиологию, патогенез и последствия ЦСА/ДЧС при наличии ХСН. 